\title{
PERAN SASTRA DALAM PENGEMBANGAN KEPRIBADIAN ANAK
}

\section{Lita Luthfiyanti dan Fithratunnisa}

\author{
STKIP-PGRI Banjarmasin \\ Jln. Sultan Adam Komplek H. Iyus, No. 18 RT. 23 Banjarmasin, \\ Kode Pos 70121. \\ e-mail: litaluthfiya@stkipbjm.ac.id
}

\begin{abstract}
Abstrak
Sastra memiliki peran sangat fundamental dalam pengembangan kepribadian anak. Hal ini disebabkan karya sastra pada dasarnya membicarakan berbagai nilai hidup dan kehidupan yang berkaitan langsung dengan pembentukkan karakter manusia. Sastra dalam pendidikan anak berperan mengembangkan bahasa, mengembangkan kognitif, afektif, psikomotorik, mengembangkan kepribadian, dan mengembangkan pribadi sosial.

Karya sastra merupakan refleksi dari kehidupan nyata sebagai hasil renungan dari realita kehidupan yang dilihat. Sastra juga menawarkan berbagai bentuk kisah yang merangsang pembaca untuk berbuat sesuatu. Apalagi pembacanya adalah anak-anak yang fantasinya baru berkembang dan menerima segala macam cerita terlepas dari cerita itu masuk akal atau tidak. Sebagai karya sastra tentulah berusaha menyampaikan nilainilai kemanusiaan, mempertahankan, serta menyebarluaskan (kepada anak-anak). Sesuai dengan sasaran pembacanya, sastra anak dikemas dalam bentuk yang berbeda dari sastra orang dewasa agar isinya dapat diterima dan difahami oleh anak-anak dengan baik. Sasta anak harus dapat membantu perkembangan kepribadian anak. Perkembangan anak akan berjalan wajar dan sesuai dengan periodenya bila disuguhi bahan bacaan yang sesuai pula. Artinya sastra anak yang memang layak dikonsumsi bagi anak-anak. Sastra yang akan dikonsumsikan bagi anak harus mengandung tema yang mendidik, alurnya lurus dan tidak berbelit-belit, menggunakan setting yang ada di sekitar mereka atau ada di dunia mereka, tokoh dan penokohan mengandung peneladanan yang baik, gaya bahasanya sederhana dan mudah dipahami tapi mampu mengembangkan kreasi, sudut pandang yang tepat, dan imajinasi masih dalam jangkauan anak.
\end{abstract}

Kata kunci: sastra anak, kepribadian

\section{Pendahuluan}

Pada hakikatnya semua orang menyenangi dan membutuhkan sastra, terlebih anak yang sedang berada dalam masa peka untuk memperoleh, memupuk, dan mengembangkan berbagai aspek kehidupan yang begitu kompleks. Anak-anak sering menanyakan atau bercerita tentang halhal yang baru saja ia alami dan ia lihat. Jika belum mendapat jawaban, anak terus meminta kita untuk menjelaskan atau menceritakannya sambil bertanya hal-hal yang didengarnya. Sudah menjadi tugas orang dewasa untuk memenuhi hak-hak anak, dan hal itu merupakan salah satu bentuk apresiasi terhadap anak. Keadaan itu, menandakan bahwa anak membutuhkan sastra dalam 
perkembangan dan pertumbuhannya. Sastra merupakan sarana yang ditawarkan untuk memenuhi kebutuhan informasi bagi anak.

Sebagaimana halnya manusia dewasa, anak pun membutuhkan inforrnasi tentang dunia, tentang segala sesuatu yang ada dan terjadi di sekelilingnya. Anak juga ingin mengetahui berbagai informasi tentang apa saja yang dapat diijangkau pikirannya Selain butuh inforrnasi anak juga perlu perhatian, pengakuan, dan penghargaan. Berbagai keperluan anak tersebut, terutama keperluan akan informasi, haruslah diusahakan untuk dipenuhi.

Pemenuhan kebutuhan tersebut pada hakikatnya adalah kewajiban kita untuk memenuhi salah satu hak anak. Anak berhak untuk memperoleh hal-hal tersebut dalam rangka pengembangan identitas diri dan kepribadiannya. Pemenuhan hak-hak anak adalah tugas kita orang dewasa, dan hal itu merupakan salah satu bentuk apresiasi terhadap anak. Pemenuhan kebutuhan anak akan informasi tersebut dapat dilakukan dan di berikan lewat cerita.

Pada hakikatnya semua orang senang dan butuh cerita, terlebih anak yang memang sedang berada dalam masa peka untuk memperoleh, memupuk, dan mengembangkan berbagai aspek kehidupan. Melalui karya sastra, misalnya cerita, anak dapat memperoleh, mempelajari, dan menyikapi berbagai persoalan hidup dan kehidupan, manusia dan kemanusiaan. Berbagai cerita menawarkan dan mendialogkan kehidupan dengan cara-cara yang menarik dan konkret. Melalui cerita juga, anak memperoleh berbagai informasi yang diperlukan dalam kehidupan. Kehidupan yang menggambarkan dan menjelaskan bagaimana hubungan dengan orang tua, teman sepermainan, dengan saudara atau masyarakat dengan berbagai peran dan fungsinya. Berbagai cerita yang dimaksudkan untuk dikonsumsikan kepada anak dapat diperoleh dan diberikan, antaralain, lewat sastra anak (children literature).

Istilah 'sastra anak' bukanlah merupakan hal yang baru, dan sudah lama kita kenal dalam bentuk cerita anak atau komik. Namun penafsiran sastra anak masih dikenal secara sempit oleh khalayak, sedangkan sastra anak tidak hanya mencakup cerita atau bacaan saja, melainkan memiliki bentuk sebagaimana sastra dewasa pada umumnya.

Sastra anak pada dasarnya merupakan "wajah sastra" yang fokus utamanya demi perkembangan anak. Di dalamnya, mencerminkan liku-liku kehidupan yang dapat dipahami oleh anak, melukiskan perasaan anak, dan menggambarkan pemikiran-pemikiran anak. Sastra anak hendaknya memiliki nilai-nilai tertentu yang dapat berpengaruh terhadap perkembangan kejiwaan anak. Yang membedakan sastra anak dengan sastra yang lain adalah muatannya. Sastra anak tentu saja perlu memuat rasa kesenangan, kegembiraan, kenikmatan, cita-cita, dan petualangan anak. Pendek kata sastra anak dapat berkisah tentang apa saja yang menyangkut masalah kehidupan, sehingga mampu memberikan informasi dan pemahaman yang lebih baik tentang kehidupan itu sendiri. 
Tidak dapat disangkal, bahwa sastra anak memiliki sumbangan yang besar bagi perkembangan kepribadian, kecerdasan, dan pengalaman anak dalam proses menuju kedewasaaan. Kematangan kepribadian, kecerdasan, dan luasnya wawasan anak dibentuk dan terbentuk melalui lingkungan di sekitarnya, termasuk lingkungan kegiatan bersasatra yang berlangsung pada kehidupan anak, baik sastra lisan yang diperoleh anak lewat saluran tuturan maupun sastra tulis yang diperoleh lewat bacaan.

Sastra sebagai sebuah karya hasil pengolahan pikiran dan perasaan seorang pengarang diyakini mampu dipergunakan sebagai media untuk menanam, memupuk, mengembangkan, dan bahkan melestarikan nilai-nilai yang diyakini baik dan berlaku pada lingkungan keluarga, masyarakat, dan bangsa. Karena adanya pewarisan nilai-nilai itulah eksistensi suatu masyarakat dan bangsa dapat dipertahankan.

\section{Metode}

Analisis ini dilakukan dalam tiga tahap utama, yaitu klasifikasi, analisis, dan penyimpulan. Tahap klasifikasi data meliputi pengumpulan data pada suatu kategori yang sama.

\section{Pembahasan}

\section{Sastra Anak}

Sastra anak berarti alat untuk mengajar anak. Cakupan sastra anak membentang luas sekali, atau yang lazim dikenal sebagai genre, bahkan melebih cakupan sastra dewasa. Ia bersifat lisan, tertulis, bahkan juga aktivitas. Sastra lisan dapat berupa cerita si ibu kepada anaknya, cerita guru kepada murid-murid TK-nya, murid-murid SD, nyanyian, dan sebagainya.

Sastra tertulis dapat berupa berbagai hal yang memang secara sengaja ditulis untuk anak dengan menekankan pentingnya unsur keindahan. Jadi, ia dapat berupa puisi, cerita fiksi, biografi tokoh, sejarah, berbagai jenis buku informasi, naskahsandiwara, dan lain-lainyang lazimnya disertai gambar-gambar menarik. Sastra aktivitas adalah sesuatu yang berupa penampilan seperti drama, baca puisi/deklamasi (Nurgiyantoro, 2005:56).

Santosa (dalam Rosdiyana, 2008:54) mengemukakan bahwa sastra anak adalah karya seni yang imajinatif dengan unsur estetisnya dominan yang bermediumkan bahasa, baik lisan maupun tertulis, yang secara khusus dapat dipahami oleh anak dan berisi tentang dunia yang akrab dengan anak-anak. Perkembangan kepribadian akan terlihat tatkala anak mencoba memperoleh kemampuan untuk mengekspresikan emosinya terhadap orang lain, dan mengembangkan perasaannya mengenai harga diri dan jati dirinya. Cerita dalam sastra anak secara tidak sadar telah mendorong atau mengajari anak untuk mengendalikan berbagai emosi. 
Sastra anak merupakan jenis sastra yang menyajikan dunia anak, memiliki karakter yang berbeda dengan sastra lainnya. Menurut Davis ( dalam Endaswara, 2005:212) ada empat sifat sastra anak, yakni: (1) tradisional, yaitu tumbuh dari lapisan rakyat sejak zaman dahulu dalam bentuk mitologi, fabel, dongeng, legenda, dan kisah kepahlawanan yang romantis; (2) idealistis, yaitu sastra yang memuat nilai-nilai universal, dalam arti didasarkan hal-hal terbaik penulis zaman dahulu dan kini; (3) populer, yaitu sastra yang berisi hiburan, yang menyenangkan anak-anak; (4) teoritis, yaitu yang dikonsumsikan kepada anak-anak dengan bimbingan orang dewasa serta penulisnya dikerjakan oleh orang dewasa pula.

Sastra anak berfungsi sebagai media pendidikan dan hiburan, membentuk kepribadian anak, serta menuntun kecerdasan emosi anak. Pendidikan dalam sastra anak memuat amanat tentang moral, pembentukan kepribadian anak, mengembangkan imajinasi dan kreativitas, serta memberi pengetahuan keterampilan praktis bagi anak. Fungsi hiburan dalam sastra anak dapat membuat anak merasa bahagia atau senang membaca, senang dan gembira mendengarkan cerita ketika dibacakan atau dideklamasikan, dan mendapatkan kenikmatan atau kepuasan batin sehingga menuntun kecerdasan emosinya.

Sastra anak hendaknya memiliki nilai-nilai tertentu yang dapat berpengaruh terhadap perkembangan kejiwaan anak. Yang membedakan sastra anak dengan sastra yang lain adalah muatannya. Sastra anak merupakan sastra yang ditujukan untuk anak, bukan sastra tentang anak. Sastra tentang anak bisa saja isinya tidak sesuai untuk anak-anak, tetapi sastra untuk anak sudah tentu sengaja dan disesuaikan untuk anak-anak selaku pembacanya. Dalam perkembangan dan pembentukan kepribadian, anak memerlukan segala informasi tentang dunia, tentang segala sesuatu yang ada dan terjadi di sekelilingnya. Anak juga ingin mengetahui berbagai informasi tentang apa saja yang dijangkau pikiranya. Informasi yang diperlukan dapat diperoleh dari berbagai sumber, seperti media cetak, media elektronika, dan buku bacaan, termasuk bacaan sastra. Namun, dalam usia yang masih sangat muda anak masih belum dapat memilih dan memilah bacaan sastra yang baik. Anak akan membaca apa saja bacaan yang ditemui dan menarik bagi dirinya., tak peduli sesuai atau tidak untuknya. Bacaan yang dikonsumsi anak tentu akan berpengaruh pada perkembangan sikap, mental, dan perilaku anak yang ditunjukkan dalam kehidupan sehari-hari. Biasanya anak akan meniru dari apa yang dilihat atau apa yang dibacanya.

Perkembangan anak akan berjalan wajar dan sesuai dengan periodenya bila disuguhi bahan bacaan yang sesuai pula. Artinya sastra anak yang memang layak dikonsumsi bagi anak-anak. Sastra yang akan dikonsumsikan bagi anak harus mengandung tema yang mendidik, alurnya lurus dan tidak berbelit-belit, menggunakan setting yang ada di sekitar mereka atau ada di dunia mereka, tokoh dan penokohan mengandung peneladanan yang baik, gaya bahasanya mudah dipahami tapi 
mampu mengembangkan bahasa anak, sudut pandang orang yang tepat, dan imajinasi masih dalam jangkauan anak.

Bacaan sastra anak dapat dimanfaatkan untuk (1) mengembangkan daya imajinasi, (2) pemahaman perbedaan bentuk, warna, jumlah, dan ukuran, (3) membangkitkan pemahaman tentang benda atau kenyataan tertentu, serta (4) membangkitkan kesadaran tentang kesehatan, kebersihan, bersikap pada orang lain dengan acuan- acuan yang bersifat konkret. Masa anak-anak (4-7 tahun) merupakan periode terpenting bagi embentukan pribadi anak. Pada masa itu anak membutuhkan kematangan emosi, fantasi atau imajinasi. Dalam berfantasi mereka kadang-kadang melambung terlalu tinggi dan jauh dari alam nyata. Atas dasar fantasi tersebut anak-anak menggemari dongeng atau cerita yang penuh keajaiban, kesaktian, jagoan dan petualangan para tokoh.

Sebagai bacaan yang dikonsumsi anak, sastra anak diyakini mempunyai kontribusi yang tidak sedikit bagi perkembangan kepribadian anak dalam proses menuju arah kedewasaan yang memiliki jati diri yang jelas. Jati diri seorang anak dibentuk dan terbentuk lewat lingkungan yang diusahakan secara atau tidak sadar. Lingkungan yang dimaksud amat luas, termasuk didalamnya sastra, baik sastra lisan yang diperoleh anak melalui tuturan maupun sastra tulis yang diperoleh melalui bacaan. Sastra yang ikonsumsi anak mampu digunakan sebagai salah satu sarana untuk menanam, memupuk, mengembangkan, dan bahkan melestarikan nilai-nilai yang baik dan berharga oleh keluarga, masyarakat, dan bangsa sejak anak masih kecil, dapat dilakukan ketika anak belum berbicara dan membaca. Misalnya dengan nyanyian yang didendangkan orang tua untuk membujuk si kecil agar segera tidur, untuk menghibur dan menyenangkan. Tentunya sastra semacam ini mengandung nilai yang berpengaruh bagi perkembangan kejiwaan bagi anak, misalnya nilai kasih sayang, perhatian dan keindahan. Perkembangan anak tidak akan wajar manakala tidak didukung kasih sayang dan perhatian. Nilai keindahan dalam nyanyian membangkitkan potensi anak untuk mengembangkan nilai seni pada dirinya, baik dalam pengertian menikmati maupun berekspresi. Pada awal perkembangan anak maka orang tualah yang mula-mula membangkitkan potensi, mengolah jiwa, dan mengajak menikmati keindahan sastra.

Sastra yang dikonsumsi anak memiliki kontribusi yang banyak, Saxby (dalam Nurgiantoro, 2005:36) mengemukakan bahwa kontribusi sastra anak membentang dari dukungan terhadap pertumbuhan berbagai pengalaman (rasa, emosi, bahasa, personal (kognitif, sosial, etis, spiritual), eksplorasi dan penemuan, namun juga petualangan dalam kenikmatan. Nurgiantoro (2005:37) menguraian nilai personal meliputi perkembangan emosional, perkembangan intelektual, perkembangan imajinasi, pertumbuhan rasa sosial, pertumbuhan rasa etis dan religius. Sedangkan nilai pendidikan meliputi eksplorasi dan penemuan, perkembangan bahasa, perkembangan nilai keindahan, penanaman wawasan multikultural, dan penanaman kebiasaan membaca. 
Anak-anak sebagai makhluk yang polos sebaiknya tidak disuguhi tulisan-tulisan atau tayangan-tayangan yang belum bisa mereka cerna dengan baik, atau belum pantas untuk mereka. Dengan begitu perkembangan anak akan berjalan sewajarnya dan sesuai dengan periodenya. Untuk itu sebagai orang tua hendaknya dapat memilih dengan benar mana sastra anak yang sebenarbenarnya. Artinya sastra anak yang memang diperuntukkan bagi anak-anak. Karena terlalu banyak orang tidak bertanggung jawab yang memanfaatkan anak-anak sebagai konsumen mereka. Baik melalui cerita anak, puisi, maupun drama (film). Untuk itu alangkah baiknya kita mengetahui hakikat sastra anak dan ciri sastra anak itu sendiri. Secara garis besar, ciri dan syarat sastra anak, yaitu:

1. Cerita anak mengandung tema yang mendidik, alurnya lurus dan tidak berbelit-belit, menggunakan setting yang ada di sekitar mereka atau ada di dunia mereka,tokoh dan penokohan mengandung peneladanan yang baik, gaya bahasanya mudah dipahami tapi mampu mengembangkan bahasa anak, sudut pandang orang yang tepat, dan imajinasi masih dalam jangkauan anak.

2. Puisi anak mengandung tema yang menyentuh, ritme yang meriangkan anak, tidak terlalu panjang, ada rima dan bunyi yang serasi dan indah, serta isinya bias menambah wawasan pikiran anak.

Namun alangkah bijaknya jika sastra anak digunakan oleh guru dan orang tua sebagai sarana mereka untuk mendidik, menghibur dan menjalin kedekatan emosi dengan anak. Oleh karena itu, temanilah dan bimbinglah anak saat membaca,mengapresiasi, mengkreasi karya. Tidak dapat disangkal lagi, bahwa sastra anak memiliki sumbangan yang besar bagi perkembangan kepribadian, kecerdasan, dan pengalaman anak dalam proses menuju kedewasaaan. Kematangan kepribadian, kecerdasan, dan luasnya wawasan anak dibentuk dan terbentuk melalui lingkungan di sekitarnya, termasuk lingkungan kegiatan bersasatra yang berlangsung pada kehidupan anak, baik sastra lisan yang diperoleh anak lewat saluran tuturan maupun sastra tulis yang diperoleh lewat bacaan.

Sastra sebagai sebuah karya hasil pengolahan pikiran dan perasaan seorang pengarang diyakini mampu dipergunakan sebagai media untuk menanam, memupuk, mengembangkan, dan bahkan melestarikan nilai-nilai yang diyakini baik dan berlaku pada lingkungan keluarga, masyrakat, dan bangsa. Karena adanya pewarisan nilai-nilai itulah eksistensi suatu masyarakat dan bangsa dapat dipertahankan. Sebagai sebuah tradisi dalam keluarga, penanaman nilai-nilai pada anak sudah berlangsung sejak anak masih dalam kandungan. Demikian pula saat anak belum mampu berbicara dan belum dapat membaca penanaman nilai-nilai pada anak semakin nyata. Nyanyian-nyanyian yang biasa didendangkan seorang ibu untuk membujuk si buah hati agar segera tidur atau sekedar membahagiakan hatinya, pada hakikatnya adalah bernilai kesastraan dan 
sekaligus mengandung nilai yang besar andilnya bagi perkembangan kejiwaan anak, misalnya nilai kasih sayang dan kejujuran.

Sosialisasi dalam rangka perkembangan sosial mengacu pada suatu proses yang digunakan oleh anak-anak untuk memperoleh perilaku, norma-norma, dan motivasi yang selalu dipantau serta dinilai oleh keluarga dan kelompok budaya mereka. Ada tiga proses yang sangat berpengaruh terhadap proses sosialisasi dalam dunia anak-anak: (1) proses reward and punishment, (2) proses imitasi atau peniruan, dan (3) proses identifikasi. Nurgiyantoro (2005:36-48) menyatakan bahwa sastra anak memiliki kontribusi bagi nilai personal dan pendidikan bagi anak. Nilai personal sastra bagi anak antara lain adalah perkembangan emosional anak, perkembangan intelektual, perkembangan imajinasi, pertumbuhan rasa sosial dan perkembangan rasa etis dan religius. Nilai pendidikan sastra bagi anak antara lain adalah membantu anak dalam hal eksplorasi dan penemuan, perkembangan bahasa, pengembangan nilai keindahan, nilai-nilai multikultural, penanaman kebiasaan dan membaca.

\section{Perkembangan Emosional}

Anak usia dini yang belum dapat berbicara, atau baru berada dalam tahap perkembangan bahasa satu kata atau kalimat dalam dua-tiga kata, sudah ikut tertawa-tawa ketika diajak bernyanyi bersama sambil bertepuk tangan. Anak tampak menikrnati lagu-lagu bersajak yang ritrnis dan larut dalam kegembiraan. Hal itu dapat dipahami bahwa sastra lisan yang berwujud puisi pada lagu tersebut dapat merangsang kegembiraan anak, merangsang emosi anak untuk bergembira, bahkan ketika anak masih berstatus bayi. Ernosi gembira yang diperoleh anak tersebut penting karena hal itu juga akan merangsang kesadaran bahwa ia dicintai dan diperhatikan. Pertumbuhan kepribadian anak tidak akan berlangsung secara wajar tanpa cinta dan kasih sayang oleh orang di sekelilingnya.

Perkembangan selanjutnya setelah anak dapat memahami cerita, baik diperoleh lewat pendengaran, misa1nya diceritakan atau dibacakan, maupun lewat kegiatan membaca sendiri, anak akan memperoleh demonstrasi kehidupan sebagaimana yang diperagakan oleh para tokoh cerita. Tokoh-tokoh cerita akan bertingkah laku baik secara verbal maupun nonverbal yang menunjukkan sikap emosionalnya, seperti ekspresi gembira, sedih, takut, terharu, simpati dan empati, benci dan dendam, memaafkan, dan lain-lain secara kontekstual sesuai dengan alur cerita.Tokoh protagonis akan menampilkan tingkah laku yang baik, sebaliknya tokoh antagonis menampilkan tingkah laku yang kurangbaik. Pembaca anak akan mengidentiflkasikan dirinya kepada tokoh protagonis sehingga sikap dan tingkah laku tokoh itu seolah-olah diadopsi menjadi sikap dan tingkah lakunya Dengan demikian, baik secara langsung maupun tidak langsung dengan membaca buku-buku cerita itu anak akan belajar bersikap dan bertingkah laku secara benar. Lewat bacaan cerita itu anak akan belajar bagaimana mengelola emosinya agar tidak merugikan diri sendiri dan orang lain. 
Kemampuan seseorang mengelola emosi istilah yang dipakai adalah Emotional Quotient (EQ) yang analog Intelegency Quotient (IQ), juga Spiritual Quotient (SQ) dewasa ini dipandang sebagai aspek personalitas yang besar pengaruhnya bagi kesuksesan hidup, bahkan diyakini lebih berperan daripada IQ.

\section{Perkembangan Intelektual}

Melalui anak tidak hanya memperoleh "kehebatan" kisah yang menyenangkan dan memuaskan hatinya. Cerita menampilkan urutan kejadian yang mengandung logika pengurutan, logika pengaluran. Logika pengaluran memperlihatkan hubungan antar peristiwa yang diperani oleh tokoh baik protagonis maupun antagonis. Hubungan yang dibangun dalam pengembangan alur pada umurnnya berupa hubungan sebab akibat. Artinya, suatu peristiwa terjadi akibat atau mengakibatkan terjadinya peristiwa-peristiwa yang lain. Untuk dapat memahami cerita itu, anak harus mengikuti logika hubungan tersebut.

Hal itu berarti secara langsung atau tidak langsung anak "mempelajari" hubungan yang terbangun itu, dan bahkan juga ikut mengritisinya. Mungkin saja anak mempertanyakan alasan tindakan-tindakan tokoh, reaksi tokoh, menyesalkan tindakan tokoh, dan lain-lain yang lebih benuansa "mengapa"-nya. Jadi, lewat bacaan yang dihadapinya itu aspek intelektual anak ikut aktif, ikut berperan, dalam rangka pemahaman dan pengkritisan cerita yang bersangkutan. Dengan kata lain, dengan kegiatan membaca cerita itu aspek intelektual anak juga ikut terkembangkan.

\section{Perkembangan Imajinasi}

Berhadapan dengan sastra, baik itu yang berwujud suara maupun tulisan, sebenamya kita lebih berurusan masalah imajinasi, sesuatu yang abstrak yang berada di dalam jiwa, sedang secara fisik sebenarnya tidak terlalu berarti. Bagi anak usia dini yang belum dapat membaca dan hanya dapat memahami sastra lewat orang lain, cara penyampaiannya masih amat berpengaruh sebagaimana halnya orang dewasa mengapresiasikan poetry reading atau deklamasi. Sastra yang notabene adalah karya yang mengandalkan kekuatan imajinasi menawarkan petualangan imajinasi yang luar biasa kepada anak. Dengan membaca bacaan cerita sastra imajinasi anak dibawa berpetualang ke berbagai penjuru dunia melewati batas waktu dan tempat, tetapi tetap berada di tempat, dibawa untuk mengikuti kisah cerita yang dapat menarik seluruh kedirian anak. Lewat cerita itu anak akan memperoleh pengalaman yang luar biasa yang setengahnya mustahil diperoleh dengan cara-cara selain membaca sastra.

Ketika anak berhadapan dengan cerita seperti Bawang Merah Bawang Putih, Cinderella, atau Harry Potter, rasanya seperti diajak berpetualang meninggalkan pijakannya di bumi. Imajinasi anak ikut berkembang sejalan dengan larutnya seluruh kedirian pada cerita yang sedang dinikmati. Ia akan segera melihat dunia dengan sudut pandang baru. Membaca sastra akan membawa anak 
keIuar dari kesadaran ruang dan waktu, keluar dari kesadaran diri sendiri, dan setelah selesai anak akan kembali ke kediriannya dengan pengalaman baru, dengan sedikit perubahan akibat pengalaman yang diperolehnya, dan dengan kemampuan berimajinasi secara lebih. Orang mustahil dapat mengembangkan seluruh kediriannya tanpa peran serta imajinasi. Daya imajinasi berkorelasi secarasignifikan dengan daya cipta. Berkat campur tangan imajinasi pula karya-karya besar, bahkan teori besar, bernunculan di hadapan kita. Hasil karya teknologi yang mengandalkan kemampuan berpikir ilmiahpun tetap membutuhkan imajinasi untuk merealisasikannya. Dengan kata-kata ekstrem dapat dikatakan bahwa tanpa imajinasi tak akan muncul karya-karya besar. Jadi, imajinasi akan memancing tumbuh dan berkembangnya daya kreativitas. Imajinasi dalam pengertian ini jangan hanya dipahami sebagai khayalan atau daya khayal saja, tetapi lebih menunjuk pada makna pemikiran yang kreatif, jadi ia bersifat produktif. Oleh karena itu, sejak dini potensi yang amat penting itu harus diberi saluran agar dapat berkembang secara wajar dan maksimal antaralain lewat penyediaan bacaan sastra.

\section{Pertumbuhan Rasa Sosial}

Bacaan cerita sastra mendemonstrasikan bagaimana tokoh berinteraksi dengan sesama dan lingkungan. Bagaimana tokoh-tokoh itu saling berinteraksi untuk bekerjasama, saling membantu, bermain bersama, melakukan aktivitas keseharian bersama, menghadapi kesulitan bersama, membantu mengatasi kesulitan oranglain, dan lain-lain yang berkisah tentang kehidupan bersama dalam masyarakat. Orang yang hidup di tengah masyarakat tidak mungkin berada dalam keadaan terisolasi tanpa berhubungan dengan orang lain. Dalam kehidupan anak akan menyadari bahwa ada orang lain di luar dirinya, dan bahwa orang akan saling membutuhkan. Kesadaran bahwa orang hidup mesti dalam kebersamaan, rasa tertarik masuk dalam kelompok, sudah mulai terbentuk ketika anak-anak berusia 3-5 tahun, dan kesadaran bahwa ada orang lain di luar dirinya bahkan sudah ada sebelurnnya. Kesadaran inilah yang kemudian dapat ditumbuhkembangkan dalam diri anak lewat bacaan sastra lewat perilaku tokoh.

Kesadaran untuk hidup bermasyarakat atau masuk dalam kelompok tersebut pada diri anak semakin besar sejalan dengan perkembangan usia. Bahkan, pengaruh kelompok dan atau kehidupan bermasyarakat tersebut akan semakin besar melebihi pengaruh lingkungan di keluarga, misalnya dalam penerimaan konsep baik dan buruk. Anak pada usia 10-12 tahun sudah mempunyai cita rasa keadilan dan peduli kepada orang lain yang lebih tinggi. Bacaan cerita sastra yang "mengeksploitasi" kehidupan bersosial secara baik akan mampu menjadikannya sebagai contoh bertingkah laku sosial kepada anak sebagaimana aturan sosial yang berlaku. 


\section{Pertumbuhan Rasa Etis dan Religius}

Selain menunjang pertumbuhan dan perkembangan unsur emosional, intelekual, imajinasi, dan rasa sosial, bacaan cerita sastra juga berperan dalam pengembangan aspek personalitas yang lain, yaitu rasa etis dan religius. Demonstrasi kehidupan yang secara konkret diwujudkan dalam bentuk tingkah laku tokoh, di dalamnya juga terkandung tingkah laku yang menunjukkan sikap etis dan religius. Sebenamya, dalam sebuah cerita keseluruh aspek personalitas manusia ditampilkan, hanya masalahnya aspek mana yang mendapat penekanan sehingga tampak dominan. Dalam cerita yang dirnaksudkan untuk menunjang perkembangan perasaan dan sikap etis dan religius, kedua aspek tersebut akan terlihat dominan. Bahkan dalam cerita anak, menginga tmasih terbatasnya jangkauan berpikir dan bernalar, penyampaian nilai-nilai pembentukan kepribadian tersebut terlihat langsung atau sedikit terselubung dalam karakter dan tingkah laku tokoh.

Nilai-niIai sosial, moral, etika, dan religius perlu ditanarnkan kepada anak sejak dini secara efektif lewat sikap dan perilaku hidup keseharian. Hal itu tidak saja dapat dicontohkan oleh orang dewasa di sekeliling anak, melainkan juga lewat bacaan cerita sastra yang juga menampilkan sikap dan perilaku tokoh. Contoh sikap dan perilaku tokoh cerita yang diberikan kepada anak, lewat cerita ibu atau membaca sendiri jika sudah bisa, dapat dipandang sebagai salah satu cara penanarnan nilainilai tersebut kepada anak. Pada umumnya anak akan mengidentifikasikan diri dengan tokoh-tokoh yang baik itu, dan itu berarti tumbuhnya kesadaran untuk meneladani sikap dan perilaku tokoh tersebut.

\section{SIMPULAN}

Perkembangan anak akan berjalan wajar dan sesuai dengan periodenya bila disuguhi bahan bacaan yang sesuai pula. Artinya sastra anak yang memang layak dikonsumsi bagi anak-anak. Sastra yang akan dikonsumsikan bagi anak harus mengandung tema yang mendidik, alurnya lurus dan tidak berbelit-belit, menggunakan setting yang ada di sekitar mereka atau ada di dunia mereka, tokoh dan penokohan mengandung peneladanan yang baik, gaya bahasanya sederhana dan mudah dipahami tapi mampu mengembangkan kreasi, sudut pandang yang tepat, dan imajinasi masih dalam jangkauan anak. Mungkin orang menganggap berlebihan jika dikatakan bahwa sastra memunyai peran penting dalam pembentukan karakter anak. Namun, sebaliknya, orang juga tidak dapat menolak fakta bahwa sastra mempunyai peran dalam pembentukan dan pengembangan kepribadian anak.

Pengakuan bahwa sastra berperan penting itu terlihat, antara lain, dari kenyataan masa lampau hingga kini orang secara sadar mengakui eksistensi sastra, mempertahankan, menikmati, dan juga menciptakannya. Dunia anak adalah dunia bermain, dunia menyanyi, dunia cerita, dunia bersenang-senang, dan tidak ada kesedihan sebagaimana kesedihan orang dewasa di sana. Sastra anak membentang luas sekali di sekeliling kita, baik berwujud lisan (cerita, nyanyian, finger ryme, 
dongeng sebelum tidur) maupun yang tertulis (cerita fiksi, cerita fantasi, cerita lama/tradisional, puisi, komik, bacaan nonfiksi, dan lain-lain). Semua itu dapat dimanfaatkan untuk kepentingan pembentukan dan pengembangan kepribadian anak agar kelak menjadi manusia yang berkarakter, manusia yang bermatabat. Sastra memberi kenikmatan kepada kita karena ia hadir untuk memberikan rasa senang, kesenangan yang menghibur yang memuaskan.

Sastra memunyai peran sebagai salah satu alat pendidikan yang seharusnya dimanfaatkan dalam dunia pendidikan, dan dalam penulisan ini dapat difokuskan pada peran dalam usaha untuk membentuk dan mengembangkan kepribadian anak, peran sebagai character building. Artinya, dapat sastra diyakini mempunyai andil yang tidak kecil dalam usaha pembentukan dan pengembangan kepribadian anak. Jika dimanfaatkan secara benar dan dilakukan dengan strategi yang benar pula, sastra diyakini mampu berperan dalam pengembangan manusia yang seutuhnya dengan cara yang menyenangkan. Tidak dapat disangkal, bahwa sastra anak memiliki sumbangan yang besar bagi perkembangan kepribadian, kecerdasan, dan pengalaman anak dalam proses menuju kedewasaaan. Kematangan kepribadian, kecerdasan, dan luasnya wawasan anak dibentuk dan terbentuk melalui lingkungan di sekitarnya, termasuk lingkungan kegiatan bersasatra yang berlangsung pada kehidupan anak, baik sastra lisan yang diperoleh anak lewat saluran tuturan maupun sastra tulis yang diperoleh lewat bacaan.

Perkembangan anak untuk sampai pada tahap kepribadian yang utuh, lahiriah dan batiniah, fisik dan spiritual, ditentukan oleh banyak faktor baik secara internal maupun eksternal yang saling berinteraksi, saling mempengaruhi, dan saling menentukan. Salah satu faktor itu adalah bacaan, khususnya bacaan sastra. Peran yang paling dekat bacaan sastra adalah membentuk anak menjadi pribadi yang gemar membaca. Gemar membaca merupakan modal penting yang kini terlihat semakin sulit ditemukan di kalangan berbagai generasi kita di Indonesia. Oleh karena itu, kebutuhanan akan kesenangan membaca cerita sedapat mungkin dapat dipenuhi. Sebagai konsekuensinya kita harus memandang penting penyediaan buku-buku bacaan anak. Curahan kasih sayang dengan membelikan berbagai keperluan anak termasuk benda-benda permainan penting, tetapi kebutuhan akan cerita dan buku jangan sampai dilupakan.

\section{Daftar Rujukan}

Agustian, Ary Ginanjar. 2007. ESQ: Emosional and Spiritual Quotient. Jakarta: ARGA Publishing.

AI-Qudsy, Huhaimin dan Ulfah Nurhidayah. 2010. Mendidik Anak Lewat Dongeng.Yogyakarta: Madina.

Endaswara, Suwardi. 2011. Metodologi Penelitian Sastra. Jakarta: Caps Publishing. 
Goleman, Daniel. 1995. Kecerdasan Emosional, Mengapa EI lebih penting daripada IQ. Terjemahan oleh T. Hermaya. 2007. Jakarta: PT Gramedia Pustaka Utama.

Lickona, Thomas. 1991. Mendidik untuk Membentuk Karakter: Bagaimana Sekolah Dapat Mengajarkan Sikap Hormat dan Tanggung Jawab. Terjemahan oleh Juma Abdu Wamaungo. 2013. Jakarta: Bumi Aksara.

Lickona, Thomas. 2004. Character Matters (Persoalan Karakter): Bagaimana Membantu Anak Mengembangkan Penilaian yang Baik, Integritas, dan Kebajikan Penting Lainnya. Terjemahan oleh Juma Abdu Wamaungo dan Jean Antunes Rudolf Zien. 2012. Jakarta: Bumi Aksara.

Nurgiyantoro, Burhan. 2005. Sastra Anak: Pengantar Pemahaman Dunia Anak. Yogyakarta: Gadjah Mada University Press.

Rosdiyana, Yusi. dkk. 2008. Bahasa dan Sastra Indonesia di SD. Jakarta: Universitas Terbuka. 